Jurnal Psikologi Teori dan Terapan

2014, Vol. 5, No. 1, 38-44 , ISSN: 2087-1708

\title{
Perbedaan komitmen Organisasi Karyawan Tetap dan Karyawan Outsourcing Pada PT. Bank Pembangunan Daerah " $X$ "
}

\author{
Jovan Januardha, dan Desi Nurwidawati \\ Program Studi Psikologi Universitas Negeri Surabaya
}

\begin{abstract}
The aim of this research was to examine the difference of organizational commitment level between regular and outsourcing employees in PT. Bank Pembangunan of " $X$ ”, Syariah Division, Branch ' $X$ ”'This research is also to examine whether the organizational commitment of regular employees is higher than the outsourcing employees. There are one independent variables and one dependt variable, they are: a). status of employees, and $b$ ). organizational commitment. The sample of this research are employees of PT. Bank Pembangunan Daerah (BPD). The amounts of sample are 60 employees, 30 regular employees, and 30 others are outsourcing employees. The technique of data analysis in this research is a Independent Samples Test. Based on this Independent Sample Test Result is 6.101 on significant level of $p=0.000(p<0.05)$. The result showed that there was a difference of organizational commitment between regular employees and outsourcing employees in PT. BPD. To conclude, the hyphothesis in this research is accepted.
\end{abstract}

Key words: Organizational commitment, regular employees, outsourcing employees.

\begin{abstract}
Abstrak: Penelitian ini bertujuan untuk mengethaui perbedaan tingkat komitmen organisasi antara karyawan tetap dan karyawan outsourcing pada PT. Bank Pembangunan Daerah (BPD) "X" Divisi Syariah Cabang "X". Penelitian ini juga menguji apakah tingkat komitmen organisasi karyawan tetap lebih tinggi daripada karyawan outsourcing. Sampel penelitian ini adalah karyawan PT.BPD "X" Divisi Syariah Cabang "X sebanyak 60 karyawan, yang terbagi menjadi 30 karyawan tetap dan 30 karyawan outsourcing. Teknik analisis data dalam penelitian ini adalah teknik independent sample test. Berdasarkan teknik analisis independent sample test diperoleh hasil uji t untuk varians sama sebesar 6, 101 dan taraf signifikasi $(p)=0,000$ $(\mathrm{p}<0,05)$. Hasil tersebut menunjukkan bahwa ada perbedaan komitmen organisasi antara karyawan tetap dan karyawan outsourcing pada PT. BPD "X" Divisi Syariah Cabang "X . Dengan kata lain, hipotesis dalam penelitian ini diterima.
\end{abstract}

Kata Kunci: Komitmen organisasi, karyawan tetap dan karyawan ousourcing

Semakin banyak usaha yang teroganisasi baik milik negara maupun swasta yang telah berdiri di Indonesia. Mereka bersaing untuk menjadi lebih unggul. Salah satunya cara untuk mencapai tujuan itu struktur dan faktor yang ada di da- lam organisasi haruslah dimaksimalkan secara baik agar tujuan organisasi secara maksimal dapat tercapai. Tujuan perusahaan pada umumnya adalah mencari keuntungan dan berusaha mempertahankan kelangsungan hidupnya dalam jangka panjang.

Korespondensi tentang artikel ini dapat dialamatkan kepada Desi Nurwidawati melalui email:desi.widawati@gmail.com. 
Segala usaha dilakukan oleh perusahaan untuk mencapai tujuan tersebut dengan menggunakan sumber daya yang tersedia.

Sember daya manusia merupakan bagian integral dan memegang peranan penting bagi perusahaan, oleh karena itu produktivitas karyawan sangatlah dituntut secara maksimal untuk mencapai kinerja yang memuaskan. Tetapi tidak jarang karyawan yang menghasilkan produktifitas rendah terhadap perusahaan karena kurang berkomitmen terhadap organisasi. Menurut Luthans (dalam Teresia dan Suyasa, 2008)

Karyawan yang berkomitmen tinggi akan memiliki produktifitas yang tinggi. Komitmen karyawan terhadap organisasi pada dasarnya merupakan suatu kondisi yang dirasakan oleh karyawan, yang dapat menimbulkan perilaku positif yang kuat terhadap organisasi kerja yang dimilikinya. Komitmen terhadap organisasi berkaitan dengan identifikasi dan loyalitas pada organisasi yang dan tujuan-tujuannya. Karyawan dengan komitmen organisasi yang tinggi memiliki perbedaan sikap dibandingkan yang berkomitmen rendah. Luthans (2008) mengatakan komitmen organisasi yang tinggi akan menghasilkan kinerja karyawan yang tinggi, rendahnya tingkat absensi dan rendahnya tingkat keluar-masuk karyawan (turn over). Sebaliknya, komitmen karyawan yang rendah memiliki dampak negatif bagi organisasi. Organisasi tidak akan mampu melakukan perubahan dengan cepat dan menampilkan kinerja yang tinggi jika tidak menimbulkan komitmen karyawannya.

Organisasi dalam mencapai tujuan dibutuhkan kinerja yang tinggi pada setiap karyawannya. Oleh karena itu, komitmen karyawan terhadap organisasi harus senantiasa dijaga dan ditingkatkan. Dalam menjaga dan meningkatkan komitmen organisasi, karyawan perlu diberikan reward dan motivasi kepada karyawan agar lebih bersemangat dalam menjalankan tugas-tugasnya dalam organisasi. Luthans (1998) mengatakan bahwa motivasi adalah proses yang membangkitkan, memberikan energi, mengarahkan, dan mempertahankan tingkah laku dan performa kerja. Seseorang akan termotivasi dengan kuat apabila kepentingan individu mereka terpenuhi. Kepentingankepentingan individu itu akan terpenuhi salah satunya oleh reward (penghargaan) yang mereka terima, sebagai imbalan dari kerja mereka.

Sistem reward (penghargaan) harus didesain untuk menghargai perilaku karyawan yang memberikan kontribusi terhadap pencapaian tujuan organisasi. Masalah reward (penghargaan) selalu mendapatkan perhatian besar dari setiap karyawan. Hal ini disebabkan karena reward (penghargaan) merupakan sumber pendapatan, merupakan penerimaan yang diperoleh karena pendi-dikan dan keterampilan yang dimilikinya, menunjukkan kontribusi kerja mereka, dan merupakan elemen dari kepuasan karyawan. Diterimanya reward (penghargaan) pada karyawan dapat mendorong karyawan merasa tenang dan bersemangat dalam menjalankan tugasnya sehingga memper-besar kinerja dan produktivitas.

Skinner (dalam Sutrisno, 2010), memaparkan konsep reinforcement yang menyatakan bahwa motivasi seseorang tergantung pada penghargaan ekstrinsik (ekstrinsic reward). Hal ini sejalan dengan teori hierarki kebutuhan Maslow (dalam Sutrisno, 2010), dimana disebutkan bahwa seseorang akan termotivasi dalam bekerja dengan tujuan pertama untuk memenuhi kebutuhan fisiologis (physiological), kemudian kebutuhan rasa aman (safety) yang dapat digolongkan dalam penghargaan ekstrinsik (extrinsic reward). Menurut Gibson dkk. (dalam Sutrisno, 2010) penghargaan ekstrinsik meliputi gaji dan upah (salary dan wage), fasilitas, jaminan sosial (fringe benefit), penghargaan antar pribadi (Interpersonal reward), serta promosi (promotion).

Moreland dkk. (1993) menyatakan bahwa komitmen organisasi akan bisa 
dicapai apabila apa yang diberikan organisasi sesuai dengan apa yang dituntut anggotanya, dan sebaliknya apa yang diharapkan organisasi sesuai dengan besarnya kontribusi anggota. Dalam prinsip ini komitmen organisasi dapat dicapai apabila sejak awal sudah ada kesepakatan reward dan cost antara kedua belah pihak. Ruvina dan Zamralita (2007) mengatakan bahwa komitmen organisasi dapat menjadi hal yang positif maupun negatif tergantung pada keadaan individu itu sendiri dan karakteristik dari organisasi yang menjadi tempat seorang bekerja. Banyak karyawan berkomitmen tinggi, yang mencapai posisi tinggi dalam perusahaan, memilih untuk tetap bertahan pada tempat bekerja sepanjang karir mereka (Miner, 1992). Namun apabila karyawan gagal dalam mendapatkan timbal balik yang sepadan dari perusahaan walaupun karyawan tersebut komitmen tinggi, maka ia dapat mengalami stress dan ketidaknyamanan dalam bekerja.

Pada zaman modern ini, perusahaan banyak melakukan pengadaan tenaga kerja dengan berbagai macam proses penerimaan. Tercatat dalam Badan Pusat Statistik (BPS) jumlah angkatan kerja di Indonesia pada Agustus 2010 mencapai 116.53 juta orang, bertambah 2.70 juta orang dibandingkan jumlah angkatan kerja Agustus 2009 dengan jumlah 113.83 juta orang atau bertambah 4.58 juta orang dibandingkan Agustus 2008 dengan jumlah 111.95 juta orang. Jumlah penduduk yang bekerja di Indonesia pada Agustus 2010 mencapai 108.21 juta, bertambah 3.34 juta orang jika dibandingkan Agustus 2009 berjumlah 104.87 juta orang atau bertambah 5.66 juta orang jika dibandingkan dengan keadaan Agustus 2008 berjumlah 102.55 juta orang.

Jumlah tenaga kerja di Indonesia yang terus meningkat menyebabkan sulit bagi perusahaan untuk menjadikan semua karyawannya sebagai karyawan tetap, dimana hal tersebut akan menghabiskan dana terlalu besar. Hal ini menyebabakan semakin maraknya pemakaian kerja kontrak atau outsourcing dalam sebuah industri perusahaan. Sehingga beberapa tahun ini, pekerja yang bersifat sementara bertambah jumlahnya. Salah satu indikatornya adalah turunnya jumlah anggota serikat pekerja. "Komposisinya itu $40 \%$ pekerja kontrak dan $60 \%$ pekerja tetap. Dulu lebih kecil," kata Peneliti Senior Akatiga, Indrasari Tjandraningsih (2010).

Pernyataan tersebut juga diperkuat oleh Kuncoro (2006) yang menjelaskan bahwa hasil studi Bank Dunia menunjukkan beberapa regulasi ketenagakerjaan dan penetapan kontrak Indonesia tidak kompetitif dibandingkan Negara lain (Malaysia, Thailand, Philpina, China dan Korea Selatan). Biaya pemecatan (termasuk pesangon) Indonesia jauh lebih tinggi dari negara lain. Hal ini menyebabkan para pengusaha mengeluh besarnya pesangon yang harus dibayarkan bila melakukan Pemutusan Hubungan Kerja (PHK), yakni mencapai 9 bulan gaji. Akibatnya, perusahaan lebih senang menarik karyawan kontrak atau outsourcing daripada karyawan tetap.

Observasi awal menunjukkan PT. Bank Pembangunan Daerah (BPD) "X" Divisi Syariah Cabang " $X$ " dalam melakukan aktivitas perbankan juga tidak terlepas dari karyawan outsourcing. Data yang diperoleh menerangkan bahwa terdapat lebih dari $40 \%$ karyawan pada bank tersebut adalah bertipe outsourcing. Berdasarkan wawancara yang telah dilakukan terdapat kesenjangan pendapat antara karyawan tetap dan karyawan outsourcing. Perbedaan ini mengacu pada perbedaan reward dan cost antara kedua macam status kepegawaian ini. Perbedaan reward dan cost antara karyawan tetap dan karyawan outsourcing antara lai meliputi upah pokok, yunjangan, fasilitas, reward serta pesangon diakhir masa kerja untuk karyawan tetap dan perpanjangan kontrak atau diangkat menjadi pegawai tetap untuk 
karyawan outsourcing yang memiliki kinerja yang baik.

Teori Pertukaran Sosial menyebutkan bahwa reward dan cost dapat meningkatkan komitmen organisasi (Moreland dkk., 1993). Sedangkan Drago dkk. (dalam Armansyah, 2002) menyebutkan bahwa pembayaran finansial juga berpengaruh terhadap komitmen organisasi. Penelitian ini bertujuan untuk menguji ada atau tidaknya perbedaan tingkat komitmen organisasi yang dilihat dari sudut pandang reward dan cost antara karyawan tetap dan karyawan outsourcing.

Berdasarkan latar belakang masalah diatas, maka rumusan masalah yang akan dibahas dalam penelitian adalah sebagai berikut: "Apakah komitmen organisasi pada karyawan tetap cenderung lebih tinggi daripada komitmen organisasi karyawan outsourcing?" Hipotesis yang diambil penelitian ini adalah komitmen organisasi pada karyawan tetap cenderung lebih tinggi daripada komitmen organisasi pada karyawan outsourcing.

\section{Metode}

Pendekatan kuantitatif dengan analisis independent sampel test digunakan penelitian ini untuk menguji perbedaan diantara dua kelompok data (variabel) atau lebih (Hasan, 2002. Dua kelompok yang dimaksudkan dalam penelitian ini adalah karyawan tetap dan karyawan outsourcing.

Analisis perbedaan atau uji perbedaan ini sering disebut uji signifikansi (tests of significance) yang digunakan untuk menguji hipotesis yaitu perbedaan komitmen organisasi antara karyawan tetap dan karyawan outsourcing.

\section{Sampel}

Populasi penelitian ini adalah seluruh karyawan PT. BPD "X" Divisi Syariah Cabang "X". Enam puluh (60) karyawan PT. Bank Pembangunan Daerah"X" Divisi Syariah Cabang "X" menjadi sampel penelitian ini yang terbagi menjadi 30 karyawan tetap dan 30 karyawan outsourcing.

\section{Teknik pengumpulan data}

Pada penelitian ini untuk mengukur komitmen organisasi digunakan skala komitmen organisasi. Skala komitmen organisasi ini dibuat berdasarkan indikatorindikator dari setiap komponen komitmen organisasi yang dikembangkan oleh Allen dan Meyer (dalam Luthans, 2008). Skala ini terdiri dari 45 Item. Masing-masing terdiri dari 4 (empat) pilihan jawaban yaitu sangat setuju, setuju, tidak setuju dan sangat tidak setuju. Semakin tinggi skor yang diperoleh berarti semakin tinggi komitmen organisasi tersebut dan semakin rendah skor yang diperoleh berarti semakin rendah komitmen organisasinya.

Berikut adalah blueprint komitmen organisasi yang memaparkan aspek variabel ini sekaligus indikatorindikatornya dan prosentase jumlah aitem pada masing-masing indikator:

Tabel 1. Bule Print Komitmen Organisasi

\begin{tabular}{ccccc}
\hline No & Aspek & \multicolumn{1}{c}{ Indikator } & $\begin{array}{c}\text { Jumlah } \\
\text { aitem }\end{array}$ & \% \\
\hline 1 & Komitmen Afektif & $\begin{array}{l}\text { a. Rasa bangga menjadi bagian dari } \\
\text { organisasi. } \\
\text { b. Perasaan nyaman ketika berada dalam } \\
\text { lingkungan organisasi. }\end{array}$ & 7 & 15,5 \\
& & $\begin{array}{l}\text { c. Kepercayaan dan penerimaan yang kuat } \\
\text { terhadap nilai-nilai dan tujuan organisasi. }\end{array}$ & 8 & 18 \\
\hline
\end{tabular}




\begin{tabular}{|c|c|c|c|c|}
\hline 2 & Komitmen Continuance & $\begin{array}{l}\text { a. Memperhitungkan unttung dan rugi jika } \\
\text { meninggalkan organisasi }\end{array}$ & 9 & 20 \\
\hline \multirow[t]{2}{*}{3} & Komitmen Normatif & $\begin{array}{l}\text { a. Tingginya loyalitas membuat seseorang } \\
\text { bertahan untuk tetap menjadi bagian dari } \\
\text { organisasi. }\end{array}$ & 7 & 15,5 \\
\hline & & $\begin{array}{l}\text { b. Merasa tetap berada dalam organisasi } \\
\text { karena rasa tanggung jawab yang besar } \\
\text { terhadap organisasi. }\end{array}$ & 7 & 15,5 \\
\hline
\end{tabular}

Jumlah

$45 \quad 100$

\section{Teknik analisis data}

Sesuai dengan hipotesis penelitian ini, teknik analisis yang digunakan untuk menganalisis data adalah Uji-t sampel independen. Uji-t sampel independen adalah metode yang digunakan untuk menguji kesamaan rata-rata dari dua populasi yang bersifat independen, dimana peneliti tidak memiliki informasi mengenai ragam populasi. Independen maksudnya adalah bahwa populasi yang satu tidak dipengaruhi atau tidak berhubungan dengan populasi yang lain.

Uji $t$ sampel independen bertujuan membandingkan dua rata-rata yang berguna untuk menguji kemampuan generalisasi dari signifikansi hasil penelitian. Penghitungan dengan uji t sampel independen ini dilakukan dengan menggunakan program SPSS versi 17.0 for Windows.

\section{Hasil dan Pembahasan}

Pengujian hipotesis dalam penelitian ini menggunakan alat bantu program SPSS (Statiscal Package for the Social Sciences) versi 17.0 for windows. Program ini merupakan program komputer yang dipakai untuk analisa statistika. Pengujian hipotesis dilakukan dengan teknik uji t dua sampel independen yang dipilih karena sesuai dengan tujuan penelitian ini yaitu melakukan analisis perbandingan terhadap lebih dari dua rata-rata.

Uji $t$ dua sampel independen digunakan untuk mencari perbedaan antara variabel dependen dengan variabel independen. Variabel dependen pada penelitian ini adalah tingkat komitmen organisasi. Variabel independen dalam penelitian ini adalah status kepegawaian yang dikelompokkan menjadi dua, yaitu karyawan tetap dan karyawan outsourcing.
Penelitian yang dilakukan pada PT. BPD "X" Divisi Syariah Cabang " $X$ " ini bertujuan untuk mengetahui perbedaan tingkat komitmen organisasi antara karyawan tetap dan karyawan outsourcing. Hasil pengujian hipotesis dengan menggunakan teknik analisis dengan menggunakan uji t dua sampel independen, menunjukkan adanya perbedaan tingkat komitmen organisasi antara karyawan tetap dan karyawan outsourcing.

Hasil data menunjukkan perbedaan skor rata-rata antara karyawan tetap sebesar 135.70 dan karyawan outsourcing sebesar 118.13. Hal ini menunjukkan bahwa karyawan tetap memiliki tingkat komitmen organisasi yang lebih tinggi dibandingkan dengan karyawan outsourcing. Hal ini sejalan dengan wawancara yang telah dilakukan dengan salah seorang karyawan PT. BPD "X" Divisi Syariah Cabang "X", kondisi dalam perusahaan perbankan ini terdapat perbedaan terhadap pemberian reward dan cost terhadap karyawannya, terlebih antara karyawan tetap dan karyawan outsourcing. Perbedaan reward dan cost antara karyawan tetap dan karyawan outsourcing pada PT. BPD "X" Divisi Syariah Cabang "X" antara lain upah pokok, tunjangan, fasilitas, reward serta pesangon diakhir masa kerja untuk karyawan tetap dan perpanjangan kontrak atau diangkat menjadi karyawan tetap untuk karyawan outsourcing yang memiliki kinerja yang baik.

Perbedaan terhadap pemberian reward dan cost pada karyawan ini memberikan perbedaan juga pada komitmen organisasi, sesuai dengan teori Teori Pertukaran Sosial yang dikemukakan oleh Moreland dkk. (1993) menyebutkan bahwa reward dan cost 
dapat meningkatkan komitmen organisasi. Teori ini menyatakan bahwa setiap hubungan yang terjadi antara pekerja dan pengusaha akan selalu mempertimbangkan untung dan rugi bagi kedua belah pihak.

Kenutungan yang didapatkan oleh organisasi dari karyawan antara lain tenaga, kemampuan, keahlian dan usaha dari setiap anggota organisasi untuk mencapai tujuan dari organisasi. Sebaliknya, karyawan akan mendapatkan balasan dari dedikasinya terhadap pencapaian organisasi diantaranya gaji, tunjangan, jamsostek, fasilitas, reward, dan pesangon diakhir masa kerja. Reward dan cost yang didapatkan karyawan dari organisasi akan membentuk kepuasan karyawan terhadap organisasi. Selanjutnya karyawan akan merasa bahwa organisasi dapat memenuhi kebutuhannya dan merasa untung menjadi anggota dari organisasi. Perasaan positif dari karyawan tersebut akan memotivasi karyawan untuk lebih berkomitmen terhadap organisasi dimana karyawan bekerja dan merasa rugi jika meninggalkan organisasi.

Status kepegawaian dibedakan menjadi 2 macam yaitu karyawan tetap dan karyawan tidak tetap atau outsourcing (Djumialdji, 2005). Perbedaan status kepegawaian antara keduanya menjadikan perbedaan juga pada reward dan cost diantara keduanya. Tjandraningsih (2010) dalam studinya menemukan perbedaan kondisi kerja dan kesejahteraan antara pekerja tetap, kontrak dan outsourcing. Perbedaan itu menyangkut upah pokok, komponen upah, upah total tunjangan, reward, fasilitas serta jamsostek. Meskipun pekerja kontrak dan outsourcing melakukan jenis pekerjaan sama, di tempat yang sama dengan jam kerja yang juga sama.

Dengan membandingkan perbedaan pada reward dan cost diantara karyawan tetap dan outsourcing menjadikan motivasi (dorongan) yang didapat dari organisasi pada karyawan outsourcing tidak sebaik karyawan tetap seperti gaji dan upah (salary dan wage), fasilitas, tunjangan, jaminan sosial (fringe benefit), penghargaan (reward), promosi (promotion), dan pesangon saat terjadi pemutusan hubungan kerja. Perbedaan ini membuat karyawan berbeda pula dan mempengaruhi tingkat komitmen organisasi antara karyawan tetap dan tidak tetap (outsourcing).

\section{Simpulan}

Dapat disimpulkan dari hasil penelitian ini bahwa terdapat perbedaan komitmen organisasi antara karyawan tetap dan karyawan outsourcing. Karyawan tetap memiliki komitmen lebih tinggi dibanding karyawan outsourcing. Perbedaan ini muncul salah satunya disebabkan oleh perbedaan dalam reward dan cost yang dialami oleh kedua kelompok karyawan tersebut.

\section{Daftar Pustaka}

Armansyah. (2002). Komitmen Organisasi dan Imbalan Finansial. Manajemen dan Bisnis, Vol. 02, No. 02 (hp://www.manbisnis.tripod.com, diakses 06 Maret 2011)

Badan Pusat Statistik. (2010). Penduduk Menurut Jenis Kelamin 2004-2010. Jakarta: Badan Pusat Stask Republik Indonesia (hp://www.bps.go.id/tab_sub/), diakses 06 Maret 2011.
Djumadi. (2004). Hukum Perburuhan Perjanjian Kerja. Jakarta: Raja Grafindo Persada.

Djumialdji, F. (2005). Perjanjian Kerja. Jakarta: Sinar Grafika.

Hasan, I. (2002). Pokok-pokok Materi Metodologi Penelitian dan Aplikasinya. Jakarta: Garlia Indonesia 
Kuncoro, M. (2006). Revisi UU Ketenagakerjaan: "Quo Vadis". Yogyakarta: Koordinator Ahli Bidang Ekonomi Regional, Pusat Studi Ekonomi dan Kebijakan Publik UGM.

(hp://www.kompas.co.id/kompascetak/0604/08/Fokus/2565669.htm, diakses 25 Februari 2011)

Luthans, F. (2008). Organizational Behavior. Lincoln: University of Nebraska Press.

1998. Organizational Behavior, Eight Edion. New York: Mc. GrowHill.

Meyer, J.P \& Allen, N.J. (1997). Commitment in the Workplace Theory Research and Application. California: Sage Publicaon.

Miner, J. B. (1992). Industrial Organizational Psychology. New York: The State University of New York at Buffalo.
Moreland, R., Levine, J., \& Cini, M., (1993) Group Socialization: The Role of Commitment. Dalam Group Motivation Social Psychology Perspectives. Editor. Michael A Hogg \& Dominic Abrams. New York: Harvester Wheatsheaf.

Ruvina, V \& Zamralita. (2007). Komitmen Organisasi: Karyawan dengan Kepribadian Tipe A dan Tipe B. Jakarta: Universitas Tarumanegara.

Sutrisno, E. (2010). Budaya Organisasi. Jakarta: Kencana.

Teresia, N. \& Suyasa, P.T.Y.S. (2008). Hubungan Komitmen Organisasi dan Organizational Citizenship Behavior pada Karyawan Call Centre PT. X. Jakarta: Universitas Tarumanegara

Tjandraningsih, I. (2010). Diskriminatif dan Eksploratif: Praktek kerja Kontrak dan Outsourcing Buruh di Sektor Industri Metal di Indonesia. Bandung: Akaga-FSPMI-FES. 